\title{
Introduction to the Colloquium: Today's Information Resource
}

Albert Sutherland

$\mathrm{T}$ The World Wide Web (Web) has become a valuable, vast information delivery system. Some would argue that it has not lived up to previous fanfare, while daily users would counter with how the Web offers convenience, speed, and an incredible array of searchable information. Millions of Web sites are online offering information on virtually every subject. Search engines are used to search Web sites for content by single words, groups of words, or phrases. Each Web user can tailor a search for the unique information they seek. Because the Web is continuously updated, information not online yesterday may be found on the Web today.

The Web overcomes the need to distribute and store information physically in a printed form. Instead, one is able to create electronic information and distribute it via computer connections. Just as the phone system allows millions of phone conversations to be transferred at the same time from one person to another worldwide, the Web provides millions of transfers of files between millions of computers within seconds.

The potential of the Web to create and distribute information easily has inspired individuals, businesses, organizations, educational institutions, and government agencies to create millions of Web pages. This has led to an incredible amount of information on virtually every subject. In addition to the text and photos found in printed media, film and audio clips can be transferred over the Web. Actual conversations and even video conferencing is possible over the Web, although quality is still lacking at this time.

While most of us are connected via wires now, some Web users receive information via digital satellite downlinks with information uplink requests made over the phone line. Within a few years, Web access will be possible over a network of low-level satellites (Montgomery, 1997). In 1998, cable modems and asymmetric digital subscriber line (ADSL) technology, with dramatically increased downlink data transmission speeds, will become more available (Hickman, 1998a; Mace, 1998).

Area extension horticulture specialist, Oklahoma State University-Grady County Extension Center, 828 West Choctaw Avenue, Chickasha, OK 73018-2310; sutherland-aj@onenet.net. 
And, 1998 is the year for introducing new encryption technology that will make purchasing over the Web more secure (Montgomery, 1998; Udell, 1998). As buying over the Internet becomes more secure, purchasing is estimated to take offlike a rocket, reaching $\$ 253$ billion by 2001 (Maclachlan, 1997). Microsoft and NetDynamics have joined forces to create improved application server software to allow companies to provide and manage secure online business transactions (Hickman, 1998b).

All this means that the Web is here to stay. The Web is not the hardware, but the connection of millions of computers. These connections will only become faster, more secure and widespread, and have greater reliability. With the Web becoming a safer place for daily business transactions and its vast array of diverse information, the Web is likely to become as common in U.S. homes in the next few years as the telephone and the television are today.

\section{HortBase-A single source of horticultural information}

HortBase is a Web horticulture information system proposed by the ASHS HortBase ad hoc committee, chaired by James L. Green. HortBase was established as a standing committee and approved for implementation by the ASHS Board of Directors in July 1997. It is expected to become a dramatic and highly recognized Web presence for ASHS. HortBase is a noncentralized, peer-reviewed, Web-linked set of horticultural information covering all areas of horticulture.

HortBase involves a number of key principles (Green et al., 1997):

- Creation of 24-hour access to reliable, nonbiased, concise, quickly retrieved, continuously updated horticulture information.

- National peer review of information to enhance information quality and use; a secondary benefit of peerreview is to provide evidence of scholarly and professional contributions of the authors for use in promotion and tenure considerations.

- Nationwide distribution of the workload and costs involved in creation, review, revision, and distribution of the electronic information.

- Establishment of authoring and reviewing guidelines in cooperation with library science and communications professionals.
HortBase is a venue for ASHS to be the recognized source of validated horticultural information on the Web. This recognition will foster positive public perceptions of horticultural professionals and the practice of horticulture. HortBase will provide a wealth of accurate, up-to-date, peer-reviewed horticultural information. It will be a source of reliable information for educators, students, industry personnel, and horticultural practitioners worldwide.

HortBase is not a luxury for ASHS, but a necessity. As the Web becomes the primary source of information for government, business, and educational leaders, only those with a strong Web presence will be considered to be at the forefront of their field. In one of the latest reports, $84 \%$ of our national senators and representatives have home pages and $\mathbf{5 8 \%}$ use the Internet regularly (Mosquera, 1998). ASHS must be present on the Web to maintain the integrity and reputation of the society and its members.

The papers presented at HortBase colloquium provide an excellent overview of HortBase.

- Jim Green focuses on the changes created by revolutionary communications tools now available.

- Considering the wide use of CDs, Ed Gilman and Jim Green show how the Web and CD technology can compliment each other.

- For an excellent overview of using the Web in education, read the paper by Roger Kjelgren and Larry Rupp.

- Mary Peet focuses on the professional challenge of going from printed media to an electronic media format.

- Dan Lineberger focuses on the role the Web plays in providing extension information and the challenges faced by the university land-grant system in the United States.

- Mary Albrecht shows how HortBase addresses four key areas of the ASHS Strategic Plan.

- Charles Emely provides a societyleadership perspective of HortBase.

- HortBase is a counterpart of Basil Eastwood's work to create agricultural databases for decision support (ADDS). Eastwood points out how we have entered a window of opportunity for creating more databases that build on the ADDS model.

To consider the many aspects of HortBase, you will want to read each paper. Use these assembled papers as a guide to how you can be a part of the
HortBase project as an author, editor, or reviewer. It will take all of our society members to make this a truly successful project. HortBase is a project that can meet the high standards of the society. HortBase provides an opportunity to make the society stronger and advance the profession of horticulture throughout the world. Now is the time for us to make HortBase the most valuable, most widely accessed horticulture information source in the world. All of the HortBase Colloquium papers are online at http://hortbase@ashs.org.

\section{Information resources cited}

Green, J.L., J. Matylonek, B. Avery, A. Duncan, E. Liss, and D. Hannaway. 1997. Hortbase: A pilot project for the USDA CSREES global information system for decision support (GISDS). http:// www.forages.css.orst.edu/HortBase/Description/hortbase.html.

Hickman, A. 1998a. The state of ADSL. PC Mag. Online 28 Jan. ZD Net. http:// www.zdnet.com/pcmag/news/trends/ t980128a.htm.

Hickman, A. 1998b. E-Commerce: The missing link. PC Mag. Online 13 Feb. ZD Net. http://www.zdnet.com/pcmag/ news/trends/t980213b.htm.

Mace, S. 1998. Broadband goes guerrilla. Byte Mag. 23(1):78. http:// www.byte.com/art/9801/sec5/ artl9.htm.

Maclachlan, M. 1997. Let the shopper beware when purchasing online. TechWeb News 31 Dec. CMP Net. http:// www.techweb.com/wire/story/ TWB19971231S0001

Montgomery, J. 1997. Fiber in the sky. Byte Mag. 22(11):58-72. http://www.byte. $\mathrm{com} / \mathrm{art} / 9711 / \mathrm{sec} 5 / \mathrm{artl}$.htm.

Montgomery, J. 1998. Transacting on the Web. Byte Mag. 23(1):81. http:// www.byte.com/art $/ 9801 / \sec 5 /$ art19.htm.

Mosquera, M. 1998. Congress gets more wired. TechWeb News 17 Feb. CMP Net. http://www.techweb.com/wire/story/ TWB19980217S0012.

Udell, J. 1998. Stop the insanity. Byte Mag. 23(1):64. http://www.byte.com/art/ $9801 /$ sec5/art6.htm. 